\title{
ESTIMATION OF THE MODULUS FIR WOOD REINFORCED WITH PBO FIBER MESH
}

\author{
P. Sokołowski ${ }^{1}$, P. G. Kossakowski ${ }^{2}$
}

\begin{abstract}
This paper presents the results of preliminary tests for estimating the modulus of elasticity of wooden beams from firs reinforced with PBO fiber mesh. The tests were carried out in the Materials Strength Laboratory at the Kielce University of Technology in Kielce, Poland with PN-EN 408: 2004. The wooden elements were subjected to a four-point bending test with the aim of estimating the elastic modulus when bending, assuming the loading velocities of the loading forces of $5 \mathrm{~mm} / \mathrm{min}$. The obtained results show a significant increase in the load-bearing capacity of beams reinforced with PBO mesh.
\end{abstract}

Key words: laboratory tests, wooden structures, mechanical properties, four-point bending.

\footnotetext{
${ }^{1}$ MSc., Eng., Kielce University of Technology, Faculty of Civil Engineering and Architecture, Al. Tysiąclecia Państwa Polskiego 7, 25-314 Kielce, Poland, e-mail: pso.sokol@wp.pl ${ }^{2}$ DSc., PhD., Eng., Kielce University of Technology, Faculty of Civil Engineering and Architecture, Al. Tysiąclecia Państwa Polskiego 7, 25-314 Kielce, Poland, e-mail: kossak@tu.kielce.pl
} 


\section{INTRODUCTION}

For millennia, people have used wood in construction. Properly secured and nurtured it can perform constructional functions for many years, not worse than other construction materials such as steel or concrete [1].

Wood is a material with a complicated structural nature, characterized by strong anisotropy [2]. These conditions, on the one hand, limit the forming of structural elements, which must be made with attention to the strong directions of the wood (along the fibers). However, on the other hand, intelligent cellular structure of wood allows obtaining favorable mechanical parameters of the material at relatively low density. Therefore, wood is still an attractive construction material that is widely used in construction.

The main disadvantage of wood is its low resistance to corrosive agents, which causes damage to components on the macro scale that reduce their load capacity. Similarly to other materials, eg structural steels [3-5], in the situation of significant deformations in the wood, destructive processes occur at the level of the microstructure. Of course, the phenomena observed in wood microstructure are different as compared to typical structural materials $[6,7]$, but the theory based on damage mechanics are succesfully applied to describe the failure processes of wood [8].

Therefore, along with the research towards the optimization of wooden structures, work is underway to repair and strengthen them. One of the modern techniques is to reinforce wood using composite materials. 
The basic parameters describing the work of beams during bending is the modulus of elasticity under bending (Young's modulus) together with the bending strength. There is a coefficient of disproportionality between the individual strain and the stress inducing it. In laboratory tests, the dependence of the deflection of the element on the load increase. When estimating the modulus of elasticity, the range in which the deformations occurring in both the compressed and stretched fibers of the cross section do not exceed the elastic deformations is analyzed and the measure of these deformations is the deflection arrow of the element. [9, 10]. According to PN-EN 408: 2004, this range has been normalized to the limit of 10\% to $40 \%$ percent of the destructive force of the element.

In this study, the value of the modulus of elasticity of fir wood reinforced with PBO fiber mesh has been estimated, as well as the factors occurring during the test, which may influence its results such as humidity, density, load speed and occurrence of material defects.

\section{DESCRIPTION OF TESTS}

\subsection{Methodology, assumptions adopted in the research}

The estimation of the general elastic modulus consists in conducting a fourpoint bending test described in PN-EN 408: 2004. The static scheme of the freedomed beam loaded symmetrically with two concentrated forces was used (Fig. 1). In order to minimize local dents, a steel washer was used between the pressures and the tested element. The applied forces were applied at a distance equal to 6 times 
the cross-section height from the axis of the supports to the upper surface of the element. The thrusts during the tests shifted with the constant speed specified in (PN-EN 408:2004):

$$
\text { load speed } \leq 0,003 \cdot h[\mathrm{~mm} / \mathrm{s}]
$$

when: $\quad h$ - height of the cross-section [millimeters]. One level of loading speed $0.5 \mathrm{~cm} / \mathrm{min}$ was assumed - for BDJ and BDJW beams: The test stand included a hydraulic MTS type testing machine (Fig. 2), inductive sensors and software recording the tested parameters. During the tests, the loading force $(\mathrm{F})$, the deflection in the middle of the span (w) and the time from the beginning to the destruction of the element were recorded continuously. The measurement of deflection was made in the level of the extreme compression fibers in the middle of the span of the element. The sensors were placed on both surfaces of the sample, and the arithmetic mean of both measurements was taken as a reliable value of deflection. After the tests, density and humidity of the elements were measured with the aid of a hygrometer WRD-100(PN-EN 384:2004).

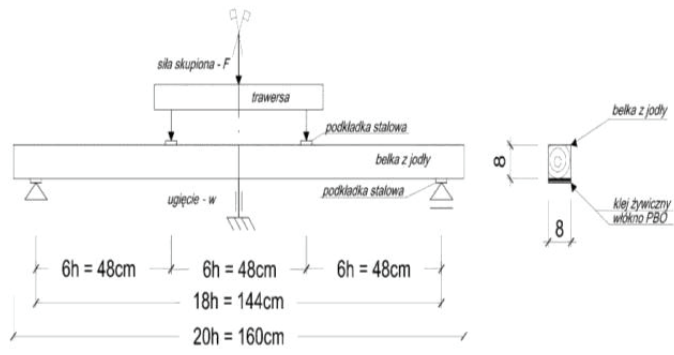

Fig. 1. Static diagram of the system for determining the modulus of elasticity of the tested wood 


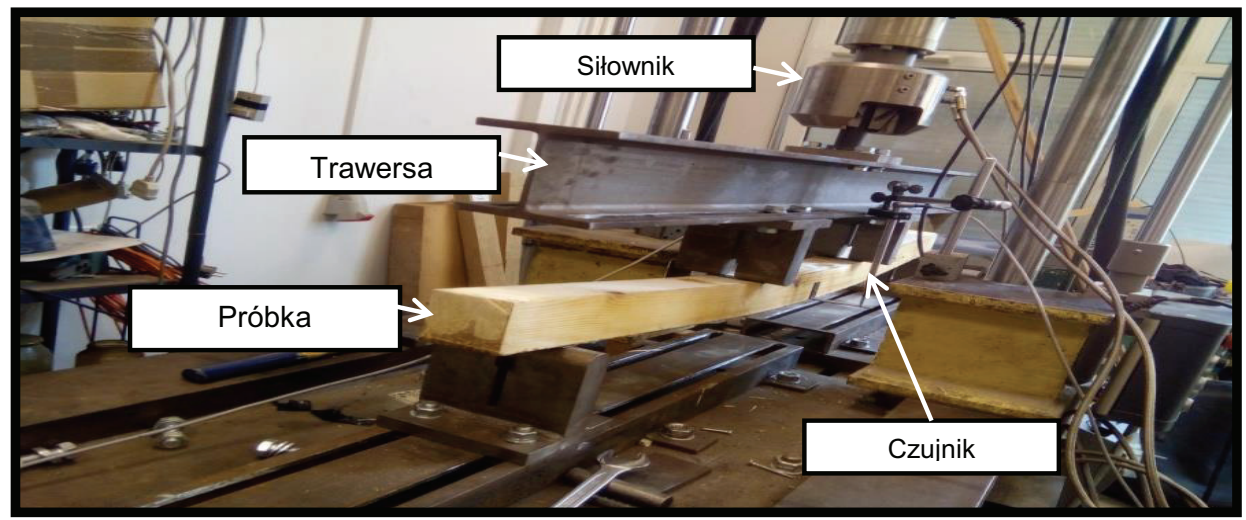

Fig. 2. Test stand for static loads

Then, on the basis of the obtained results of laboratory tests, the elastic coefficient for bending according to the formula was determined (PN-EN 408:2004):

$$
E_{m, g}=\frac{l^{3}\left(F_{2}-F_{1}\right)}{b h^{3}\left(w_{2}-w_{1}\right)}\left[\left(\frac{3 a}{4 l}\right)-\left(\frac{a}{l}\right)^{3}\right]
$$

when: $\quad b$

$$
\text { width of the cross-section [millimiters], }
$$

height of the cross-section [millimiters], span of the tested element in the axes of supports

[millimiters],

$$
\begin{aligned}
& F_{2}-F_{1} \quad \text { load increase in the linear range [w niutonach], } \\
& w_{2}-w_{1} \quad \text { deflection increase corresponding to the load increase } \\
& \text { [millimiters], } \\
& \text { a distance from the point of application of concentrated force }
\end{aligned}
$$
to the nearest support according to Fig. 1 [millimiters].

Destructive tests make it possible to obtain a more accurate value of bending strength and to determine the area necessary to work out the results. The general 
modulus of elasticity can also be determined by not destroying the analyzed element, limiting the area of load-deflection analysis to the range of $10 \%$ to $40 \%$ of the breaking force value.

\subsection{Material}

10 pieces of $8 \times 8 \times 160 \mathrm{~cm}$ wooden beams made of fir were used for the tests. 5 wooden beams were used as witnesses - unreinforced (marked BDJ), others were reinforced with the bottom with PBO fiber mesh glued with resin adhesive (marked BDJW). Wooden beams were purchased own resources, and the remaining materials, like PBO mesh and Resin 55 adhesive, were obtained free of charge from Visbud - Projekt Sp. z o. Wrocław and from S \& P Malbork. The research was not carried out with full-size elements due to the limited amount of material to be analyzed. Norm PN-EN 408: 2004 and the abilities of the hydraulic strength machine used In the test determine the dimensions of the samples tested (Table 1.2). Prior to the study, photographic documentation was made, material defects were identified and the elements were characterized (Fig. 3, table 1,2) material defects, elements have been characterized taking into account their geometries and basic properties (Table 1.2).

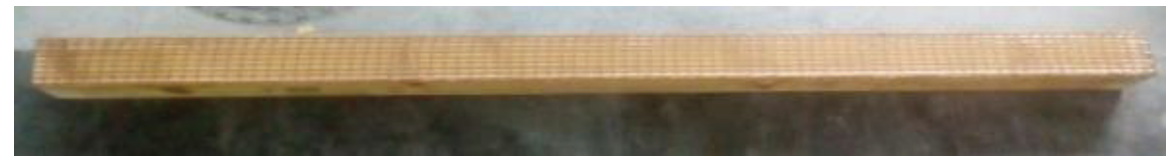

Figure 3. BDJW fir sample top view 
Tab. 1. Dimensions and basic physical properties of the tested elements (BDJ)

\begin{tabular}{|c|c|c|c|c|}
\hline $\begin{array}{c}\text { Beam } \\
\text { (mark) }\end{array}$ & $\begin{array}{c}\text { Nominal } \\
\text { dimensions } b x h x L \\
{[\mathrm{~m}]}\end{array}$ & $\begin{array}{c}\text { Mass } \\
{[\mathrm{kg}]}\end{array}$ & Density $\left[\mathrm{kg} / \mathrm{m}^{3}\right]$ & $\begin{array}{c}\text { Description of } \\
\text { samples }\end{array}$ \\
\hline BDJ 1 & $0,08 \times 0,08 \times 1,60$ & 4,321 & 4,219 & $\begin{array}{c}\text { Element in good } \\
\text { condition. Knots are } \\
\text { visible on the side } \\
\text { surfaces. }\end{array}$ \\
\hline BDJ 2 & $0,08 \times 0,08 \times 1,60$ & 4,425 & 4,321 & $\begin{array}{c}\text { Element in good } \\
\text { condition. Knots are } \\
\text { visible on the side } \\
\text { surfaces.. }\end{array}$ \\
\hline BDJ 3 & $0,08 \times 0,08 \times 1,60$ & 4,439 & 4,334 & $\begin{array}{c}\text { Element in good } \\
\text { condition. Knots are } \\
\text { visible on the side } \\
\text { surfaces. }\end{array}$ \\
\hline BDJ 4 & $0,08 \times 0,08 \times 1,60$ & 4,381 & 4,278 & $\begin{array}{c}\text { Element in good } \\
\text { condition. Knots are } \\
\text { visible on the side } \\
\text { surfaces. }\end{array}$ \\
\hline BDJ 5 & $0,08 \times 0,08 \times 1,60$ & 4,374 & 4,271 & $\begin{array}{c}\text { Element in good } \\
\text { condition. Knots are } \\
\text { visible on the side } \\
\text { surfaces. }\end{array}$ \\
\hline
\end{tabular}


Tab. 2. Dimensions and basic physical properties of the tested elements (BDJW)

\begin{tabular}{|c|c|c|c|c|}
\hline $\begin{array}{c}\text { Beam } \\
\text { (mark) }\end{array}$ & $\begin{array}{c}\text { Nominal } \\
\text { dimensions } b x h x L \\
{[\mathrm{~m}]}\end{array}$ & $\begin{array}{c}\text { Mass } \\
{[\mathrm{kg}]}\end{array}$ & Density $\left[\mathrm{kg} / \mathrm{m}^{3}\right]$ & $\begin{array}{c}\text { Description of } \\
\text { samples }\end{array}$ \\
\hline BDJW 1 & $0,08 \mathrm{x} 0,08 \mathrm{x} 1,60$ & 4,769 & 4,657 & $\begin{array}{c}\text { Element in good } \\
\text { condition. Knots are } \\
\text { visible on the side } \\
\text { surfaces. }\end{array}$ \\
\hline BDJW 2 & $0,08 \mathrm{x} 0,08 \times 1,60$ & 5,370 & 5,244 & $\begin{array}{c}\text { Element in good } \\
\text { condition. } \\
\text { No material defects }\end{array}$ \\
\hline BDJW 3 & $0,08 \times 0,08 \times 1,60$ & 4,524 & 4,410 & $\begin{array}{c}\text { Element in good } \\
\text { condition. Knots are } \\
\text { visible on the side } \\
\text { surfaces. }\end{array}$ \\
\hline BDJW 4 & $0,08 \times 0,08 \times 1,60$ & 4,625 & 4,516 & $\begin{array}{c}\text { Element in good } \\
\text { condition. Knots are } \\
\text { visible on the side } \\
\text { surfaces. }\end{array}$ \\
\hline BDJW 5 & $0,08 \times 0,08 \times 1,60$ & 4,476 & 4,371 & $\begin{array}{c}\text { Element in good } \\
\text { condition. Knots are } \\
\text { visible on the side } \\
\text { surfaces. }\end{array}$ \\
\hline
\end{tabular}




\section{RESULTS AND DISCUSSION}

In Table 2, values of the elastic modulus for individual samples of unreinforced beams together with the components necessary for its calculation are presented, and in Table 3 for reinforced beams.

Beams reinforced with PBO mesh were characterized by the longest test time. The greatest increase in load capacity and deflection was obtained compared to unreinforced beams. Destruction of the sample occurred quickly after exceeding the maximum bending moment after reaching the tensile strength in the extreme lower fibers. It was characterized by a sudden and brittle fracture of the material. The greatest value of the elastic modulus was noted for the BDJW3 beam and the highest value of the destructive force for the BDJW2 beam, which was characterized by the absence of material defects (knots). The lack of influence of the element load speed on the achieved values was also noticed

The correlation coefficient between load and deflection measured in the range of the force loading the element from $0.1 \mathrm{~F}$ _max to $0.4 \mathrm{~F}$ _maxy for all elements was at least 0.999 (positive correlation).

The humidity measured after the tests ranged from $19 \%$ to $20 \%$. 
Tab. 3. List of research results (BDJ).

\begin{tabular}{|c|c|c|c|c|c|}
\hline Beam & $\begin{array}{c}\text { The } \\
\text { destructive } \\
\text { power } \\
F_{\text {max }}[N]\end{array}$ & $\begin{array}{c}\text { Increase in } \\
\text { strength } \\
F_{2}-F_{1} \\
{[N]}\end{array}$ & $\begin{array}{c}\text { Deflection } \\
{[\mathrm{mm}]}\end{array}$ & $\begin{array}{c}\text { increase of } \\
\text { deflection } \\
w_{2}-w_{1}[\mathrm{~mm}]\end{array}$ & $\begin{array}{c}\text { Modulus of } \\
\text { elasticity } E_{m, g} \\
{[\mathrm{GPa}]}\end{array}$ \\
\hline BDJ 1 & 9564,3 & 2869,3 & 24,5 & 6.5 & 6,7 \\
\hline BDJ 2 & 15002,9 & 4500,8 & 23,4 & 6.4 & 10,8 \\
\hline BDJ 3 & 14128,9 & 4238,6 & 28,2 & 6.8 & 9,6 \\
\hline BDJ 4 & 12383,8 & 3715,1 & 23,5 & 6.4 & 8,8 \\
\hline BDJ 5 & 16208,4 & 4862,5 & 36,8 & 9.5 & \\
\hline
\end{tabular}


Tab. 4. List of research results (BDJW).

\begin{tabular}{|c|c|c|c|c|c|}
\hline Beam & $\begin{array}{c}\text { The } \\
\text { destructive } \\
\text { power } \\
F_{\text {max }}[N]\end{array}$ & $\begin{array}{c}\text { Increase } \\
\text { in strength } \\
F_{2}-F_{1} \\
{[N]}\end{array}$ & $\begin{array}{c}\text { Deflection } \\
{[\mathrm{mm}]}\end{array}$ & $\begin{array}{c}\text { increase of } \\
\text { deflection } \\
w_{2}-w_{1}[\mathrm{~mm}]\end{array}$ & $\begin{array}{c}\text { Modulus of } \\
\text { elasticity } E_{m, g} \\
{[G P a]}\end{array}$ \\
\hline $\begin{array}{c}\text { BDJW } \\
1\end{array}$ & 19163,3 & 5748.9 & 47,4 & 9.4 & 9,4 \\
\hline $\begin{array}{c}\text { BDJW } \\
2\end{array}$ & 27597,7 & 8279.3 & 60 & 17.1 & 7,4 \\
\hline $\begin{array}{c}\text { BDJW } \\
3\end{array}$ & 20246,5 & 5700.9 & 50 & 8.6 & 10,2 \\
\hline $\begin{array}{c}\text { BDJW } \\
4\end{array}$ & 19003,0 & 5700.9 & 42 & 8.6 & 10,1 \\
\hline BDJW & 19104,0 & 5731.2 & 42 & 9.8 & 8,9 \\
\hline 5
\end{tabular}

This paper presents a graph of load-time dependence (Fig. 4) and load-deflection (Fig. 5) for the entire test run up to destruction. Statistical analysis was carried out for a range of values from $0.1 \mathrm{~F} \_$max to $0.4 \mathrm{~F} \_$max. 


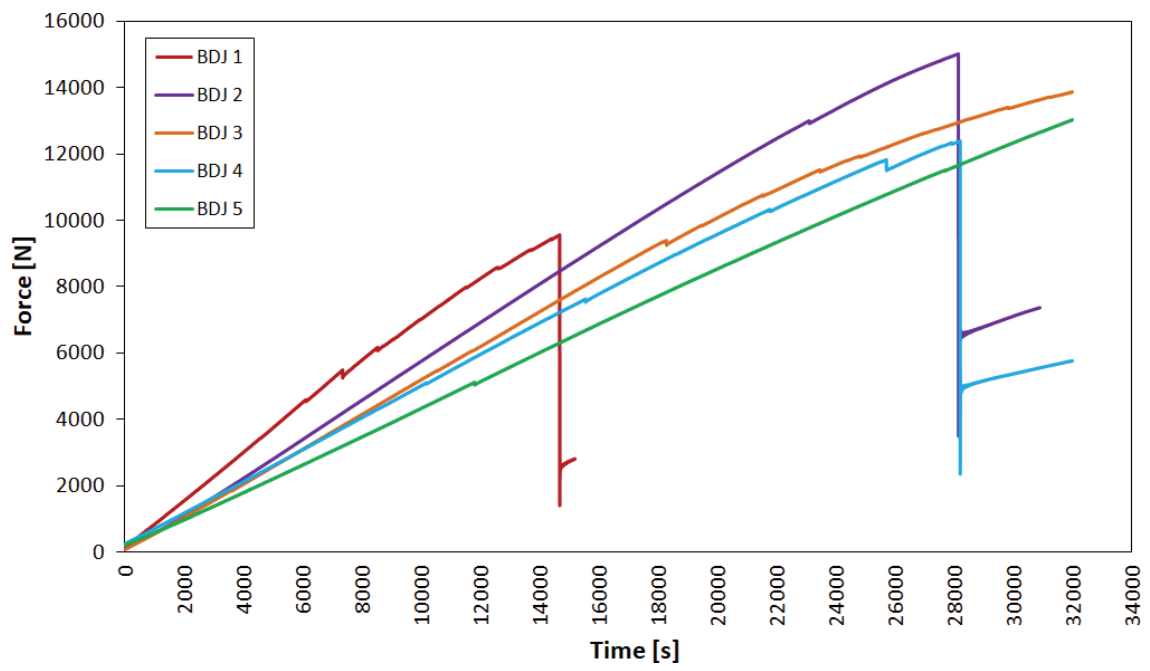

Fig. 4. Diagram of the " load - time" relationship for the tested BDJ elements

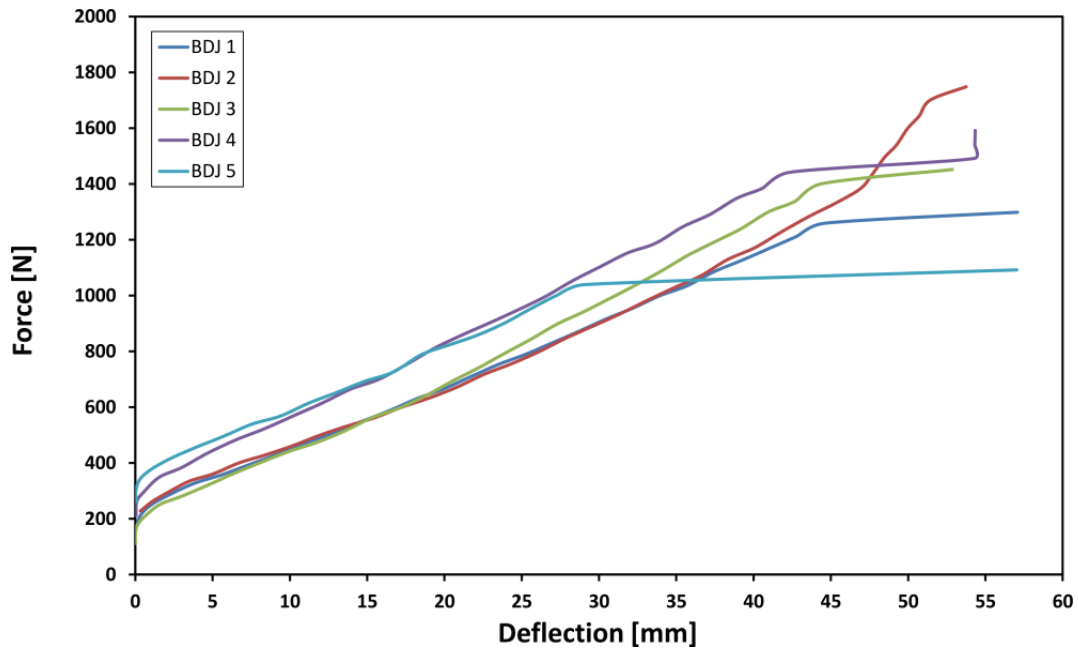

Fig. 5. Graph of dependence "load - deflection" for the tested elements of BDJW 
Measurements of deflections carried out by means of inductive sensors measured in the level of the upper compression fibers in the middle of the beam span are characterized by abrupt changes in values. The effect of such changes in the course is caused by sudden cracks of the element resulting from the achievement of tensile strength in the case of reinforced elements.

Tab. 5. List of statistical analysis of BDJ research results

\begin{tabular}{|c|c|c|c|c|}
\hline Beam & $\begin{array}{c}\text { The destructive } \\
\text { power } \\
F_{\text {max }}[\mathbf{N}]\end{array}$ & $\begin{array}{c}\text { Increase in } \\
\text { strength } \\
F_{2}-F_{1} \\
{[N]}\end{array}$ & $\begin{array}{c}\text { Deflection } \\
{[\mathbf{m m}]}\end{array}$ & $\begin{array}{c}\text { increase of } \\
\text { deflection } \\
\mathbf{w}_{2}-\boldsymbol{w}_{1} \\
{[\mathbf{m m}]}\end{array}$ \\
\hline $\begin{array}{c}\text { Average } \\
\text { arithmetical }\end{array}$ & 13457 & 4037 & 7,1 & 8,8 \\
\hline $\begin{array}{c}\text { Deviation } \\
\text { standard }\end{array}$ & 2311 & 693 & 1,2 & 1,4 \\
\hline $\begin{array}{c}\text { Coefficient of } \\
\text { variation }\end{array}$ & 0,71 & 0,7 & 0,1 & 0,1 \\
\hline
\end{tabular}


Tab. 6. Statistical analysis of the results

\begin{tabular}{|c|c|c|c|c|}
\hline Beam & $\begin{array}{c}\text { The destructive } \\
\text { power } \\
\boldsymbol{F}_{\text {max }}[N]\end{array}$ & $\begin{array}{c}\text { Increase in } \\
\text { strength } \\
F_{2}-F_{1}[N]\end{array}$ & $\begin{array}{c}\text { Deflection } \\
{[\mathbf{m m}]}\end{array}$ & $\begin{array}{c}\text { increase of } \\
\text { deflection } \\
\boldsymbol{w}_{2}-\boldsymbol{w}_{1} \\
{[\mathrm{~mm}]}\end{array}$ \\
\hline $\begin{array}{c}\text { Average } \\
\text { arithmetical }\end{array}$ & 21022,9 & 6232,2 & 10,7 & 9,2 \\
\hline $\begin{array}{c}\text { Deviation } \\
\text { standard }\end{array}$ & 3318,1 & 1023,6 & 3,2 & 0,9 \\
\hline $\begin{array}{c}\text { Coefficient } \\
\text { of variation }\end{array}$ & 0,15 & 0,16 & 0,29 & 0,1 \\
\hline
\end{tabular}

Tab.7. Comparison of BDJ research results with BDJW

\begin{tabular}{|c|c|c|c|}
\hline Considered parameter & $\begin{array}{c}\text { Reference beams - } \\
\text { BDJ }\end{array}$ & $\begin{array}{c}\text { Beams reinforced } \\
\text { with mesh PBO- } \\
\text { BDJW }\end{array}$ & $\begin{array}{c}\text { Increase } \\
{[\%]}\end{array}$ \\
\hline $\begin{array}{c}\text { Destructive force [N] } \\
\text { [Nlexural strength } \\
\text { [MPa] }\end{array}$ & $\mathbf{1 3 4 5 7}$ & $\mathbf{2 1 0 2 2}$ & $\mathbf{5 6}$ \\
\hline $\begin{array}{c}\text { Modulus of elasticity } \\
\text { [GPa] }\end{array}$ & $\mathbf{3 7}$ & $\mathbf{5 9}$ & $\mathbf{5 6}$ \\
\hline $\begin{array}{c}\text { Deflection at maximum } \\
\text { force [mm] }\end{array}$ & $\mathbf{8 . 8}$ & $\mathbf{9 , 2 5}$ & $\mathbf{4 , 9}$ \\
\hline $\begin{array}{c}\text { Time to achieve destruction } \\
{[\text { [sek] }}\end{array}$ & $\mathbf{2 9 8}$ & $\mathbf{5 8 2}$ & $\mathbf{9 5}$ \\
\hline
\end{tabular}




\section{CONCLUSIONS}

The paper presents the results of the estimation of the modulus of elasticity of fir wood reinforced with PBO fiber mesh and the basic assumptions of the algorithm of laboratory tests for determining the modulus of wood elasticity in accordance with the requirements of PN-EN 408: 2004. On the basis of the analysis of the results of four-point bending tests, it was observed:

- significant increase of destructive force, modulus of elasticity,

- significant increase of deflection and time needed to destroy the sample,

- no impact of the element load speed on the achieved values,

- high value of the correlation coefficient between load and deflection.

It was also observed that the destruction of the sample occurred quickly after exceeding the maximum bending moment after reaching the tensile strength in the extreme lower fibers. It was characterized by a sudden and brittle fracture of the material.

One should also note the possibility of re-registering measurements measuring the deflection of the element due to the location of inductive sensors. Sudden weakening of the cross-section (cracks) caused by the increasing load (visible as abrupt changes in the graph of the deflection-time relationship) may result in the displacement of the test apparatus.

In conclusion, it can be concluded that the PBO fiber mesh is a good solution for reinforcing beams and other bending elements. Visible influence on this has the increase of destructive force of elastic modulus. Nevertheless, the problem of this 
type of reinforcement due to the complexity of the mechanical and physical features of wood requires a more extensive analysis allowing to formulate conclusions that will be important from the point of view of statistical analysis.

\section{ACKNOWLEDGEMENTS}

Special thanks to Dr. Eng. Mariusz Jackiewicz from Visbud - Projekt Sp. z o. o. from Wrocław for donating of the PBO net and Mr. Marcin Warzyński from S \& $\mathrm{P}$ from Malbork for free Resinn 55 glue for conducting our research.

\section{REFERENCES}

1. Kotwica J (2004) Konstrukcje drewniane w budownictwie tradycyjnym Arkady, Warszawa.

2. P. G. Kossakowski, "Influence of anisotropy on the energy release. rate $\mathrm{G}_{\mathrm{I}}$ for highly orthotropic materials", Journal of Theoretical and Applied Mechanics: 45, 739-752, 2007.

3. P. G. Kossakowski, "Stress Modified Critical Strain criterion for S235JR steel at low initial stress triaxiality", Journal of Theoretical and Applied Mechanics: 52, 995-1006, 2014.

4. P. G. Kossakowski, W. Wciślik, "Effect of critical void volume fraction $f_{F}$ on results of ductile fracture simulation for S235JR steel under multi-axial stress states", Key Engineering Materials - Fracture and Fatigue of Materials and Structures 598: 113-118, 2014.

5. P. G. Kossakowski, "An analysis of the Tvergaard parameters at low initial stress triaxiality for S235JR steel”, Polish Maritime Research: 21, 100-107, 2014

6. Mazars J.: A description of micro- and macroscale damage of concrete structures, Engineering Fracture Mechanics 25(5-6) (1986), pp. 729-737.

7. Chaboche J. L., Lesne P. M., Maire J. F.: Continuum Damage Mechanics, Anisotropy and Damage Deactivation for Brittle Materials Like Concrete and Ceramic Composites, International Journal of Damage Mechanics 4(1) (1995), pp. 5-22.

8. Sandhaas C., Van de Kuilen J.W., Blass H.J.: Constitutive model for wood based on continuum damage mechanics, WCTE, World conference on timber engineering, Auckland, New Zealand, 15-19 July 2012, pp. 159-167. 
9. Stefańczyk B (2005) Budownictwo ogólne. Materiały i wyroby budowlane. Tom 1. Arkady, Warszawa.

10. Rudziński L (2010) Konstrukcje drewniane. Naprawy, wzmocnienia, przykłady obliczeń.Wydawnictwo Politechniki Świętokrzyskiej, Kielce.

11. PN-EN 408:2004 Konstrukcje drewniane. Drewno konstrukcyjne i klejone warstwowo. Oznaczanie niektórych właściwości fizycznych i mechanicznych.

12. PN-EN 384:2004 Drewno konstrukcyjne.Oznaczanie wartości charakterystycznych właściwości mechanicznych i gęstości.

13. Nowak T, Brol J, Jasieńko J(2013) Estimation of the strength parameters of wood in building structures - preliminary studies. Forestry and Wood Technology nr 83: 303-306. 